\title{
Bases de données et gestion de projets en humanités numériques
}

Les dessous du projet Artl@s

Databases and project management in digital humanities. Inside Project Artl@s Bases de datos y gestión de proyectos de humanidades numéricas. Bambalinas del proyectoArtl@s

\section{Béatrice Joyeux-Prunel}

\section{(2) OpenEdition}

\section{Journals}

Édition électronique

URL : http://journals.openedition.org/bssg/242

DOI : $10.4000 /$ bssg. 242

ISSN : 2490-9424

Éditeur

Presses universitaires de Vincennes

Référence électronique

Béatrice Joyeux-Prunel, «Bases de données et gestion de projets en humanités numériques », Biens Symboliques / Symbolic Goods [En ligne], 2 I 2018, mis en ligne le 12 avril 2018, consulté le 04 mars 2021. URL : http://journals.openedition.org/bssg/242 ; DOI : https://doi.org/10.4000/bssg.242 


\section{Bases de données et gestion de projets en humanités numériques}

Les dessous du projet Artl@s

\section{Databases and Project Management in Digital Humanities}

Inside Project ArtI@s

\author{
Béatrice Joyeux-Prunel
}

traduction | translation

Michelle Arriss | Delaina Haslam | Séverine Sofio

\begin{abstract}
Comment est né le projet de base de données ?
Le projet ARTL@S met à disposition des chercheur.se.s une base numérique de catalogues d'expositions partout dans le monde aux $\mathrm{XIX} \mathrm{X}^{\mathrm{e}}$ et $\mathrm{XX}$ siècles. Les adresses contenues dans ces catalogues sont géoréférencées, quelles que soient les époques et les géographies. Cet outil est pensé pour permettre aussi bien des recherches monographiques qu'un travail sur les circulations des œuvres d'art, la construction des carrières et des goûts dans ce processus circulatoire. Centralisant et permettant de croiser des sources souvent difficiles d'accès, la base ARTL@S doit contribuer à renouveler l'histoire internationale des expositions et de la culture qui y est associée. À terme, elle sera mise à disposition des publics. ARTL@S est financé par l'École normale supérieure (ENS) Paris, l'Agence nationale de la recherche (ANR, projet Jeunes-Chercheurs 2011-2016), PSL Research University Paris,
\end{abstract}

\section{How did the database project begin?}

The ARTL@S project offers researchers a digital database of catalogues of exhibitions held all over the world during the nineteenth and twentieth centuries. The addresses contained in these catalogues are geo-referenced, regardless of era and geography. The tool is designed to enable monographic research as well as a study of the circulation of works of art, and the construction of careers and tastes in this process. Through its capacity to centralize and cross-reference sources that are often difficult to access, the ARTL@S database aims to breathe new life into the international history of exhibitions and the culture associated with them. It has just been opened to the public and it is accessible from the project's central online portal. ARTL@S is financed by the École normale supérieure (ENS) Paris, l'Agence Nationale de la Recherche (ANR, Projet Jeunes-Chercheurs 
I'Institut d'histoire moderne et contemporaine (UMR 8066, CNRS/ ENS) et par le laboratoire d'excellence TransferS (programme Investissements d'avenir ANR-10-IDEX-0001-02 PSL* et ANR-10LABX-0099). II est dirigé par Béatrice Joyeux-Prunel (ENS Paris), avec la collaboration de Catherine Dossin (Purdue University, États-Unis) et Léa Saint-Raymond (Université de Nanterre).

Ce projet s'enracine au début des années 2000, dans une équipe de doctorant $\cdot e \cdot s$ puis de docteur.e.s en histoire et en histoire de l'art et de la littérature. Nous étions attirés par les ambitions explicatives d'une histoire sociale, quantitative, comparée et transnationale inspirée par Fernand Braudel et la première École des Annales, nourrie de l'héritage de Pierre Bourdieu et des problématiques des transferts culturels. Nous voulions donc prendre en compte des périodes longues, réaliser nos études sur plusieurs échelles, mettre en relation le niveau de la microhistoire et celui de la macrohistoire. Nous utilisions une démarche quantitative pour mieux cibler nos coups de sonde monographiques. Le développement des outils informatiques permettait en outre de reprendre le meilleur de I'héritage des Annales, avec la certitude qu'en n'abandonnant pas pour autant les analyses ponctuelles détaillées, ni l'histoire vécue (témoignages contemporains ou postérieurs à un événement) ni enfin les œuvres elles-mêmes, on pouvait tenter une histoire plus contextualisée et plus explicative. L'idée était de comprendre les grandes forces à l'œuvre dans l'histoire des arts et des lettres, un peu mieux qu'à l'aide d'histoires morcelées de créateurs ou de mouvements, isolés de contextes plus larges et trop souvent présentés comme exceptionnels.
2011-2016), PSL Research University Paris, I'Institut d'histoire moderne et contemporaine (UMR 8066, CNRS/ENS), and the laboratoire d'excellence TransferS (programme Investissements d'avenir ANR-10-IDEX-0001-02 PSL* et ANR-10-LABX-0099). It is headed up by Béatrice Joyeux-Prunel (ENS Paris) in collaboration with Catherine Dossin (Purdue University, USA) and Léa SaintRaymond (Université de Nanterre).

The project has its roots in the early 2000s, with a team of doctoral students and young scholars in history, history of art and literature. We were searching for a social, quantitative, comparative, and transnational social history inspired by Fernand Braudel and the first École des Annales, and we were also nurtured by the legacy of Pierre Bourdieu and wanted to take into account issues of cultural transfer. We wanted, therefore, to carry out our studies on long periods of time and various scales, while working on both the levels of micro-history and of macro-history. We used a quantitative approach to better pinpoint our monographic spotchecks. The development of data processing tools enabled us, among other things, to take up the best of the Annales legacy with the certain knowledge that by not abandoning detailed and timely analysis, nor lived history (contemporary or past accounts of an event), nor, finally, the artworks themselves, we could move towards a more contextualized and explanatory history. That way, we thought that the forces at work in the history of art and literature could be seen more clearly than under the partial light of decontextualized histories of creators and movements, too often presented as exceptions. 
En thèse, j'avais moi-même réalisé une base de catalogues d'expositions pour étudier la circulation internationale des œuvres de l'avant-garde parisienne entre les années 1850 et $1914^{1}$. Cette base me permit de travailler sur l'internationalisation des trajectoires, des réputations et des esthétiques, avant d'aborder des études plus traditionnelles, adossées à une reconstitution préalable de logiques structurelles. D'autres travaillaient aussi à des bases de données, ou voulaient se former aux approches quantitatives. Chacun se sentait un peu seul avec ses tableurs. D'où l'idée à mon arrivée à l'ENS en 2007 d'organiser un séminaire, " art et mesure », dans lequel Claire Lemercier, passionnée de méthodes quantitatives, nous aida à mieux cadrer nos manières de faire. Lors du colloque «Art et Mesure » organisé à l'ENS en décembre 2008, j'ai pu voir que nous étions nombreux à mettre en base des catalogues d'expositions. Pourquoi ne pas regrouper nos données ? II était clair en particulier qu'une base numérique de catalogues d'expositions à l'échelle mondiale, et sur une longue période, serait des plus utiles pour l'histoire de l'art.

Ma propre base d'expositions et de catalogues constituait un bon départ ; j'en avais donné une partie au projet base Salons du musée d'Orsay, mais Orsay n'était intéressé que par les expositions organisées en France et par l'institution, donc de type académique. L'Institut national d'histoire de l'art (INHA), contacté aussi en 2006 , était intéressé mais rien n'avançait. Nous avons donc commencé à travailler seuls avec l'aide financière de l'ENS. L'idée est vite venue de faire de la base un système d'information géographique (SIG) - donc de donner la possibilité d'y cartographier les adresses, si nombreuses, contenues dans les catalogues d'expositions. Il a fallu

1 Cette thèse a été soutenue en histoire sous la direction de Christophe Charle à l'Université Paris 1 - Panthéon Sorbonne, en 2005, puis publiée en 2009 sous forme de livre (prix du Musée d'Orsay).
For my PhD thesis, I created a database of exhibition catalogues in order to study the international circulation of Parisian avant-garde works from 1850 to $1914 .^{1}$ Thanks to this database I was able to study the internationalization of trajectories, reputations, and aesthetics, before undertaking more traditional studies, supported by a preliminary reconstitution of structural logics. At the same time, several other colleagues were also working on databases or wanted to learn about quantitative approaches, but everyone was feeling somewhat isolated with his or her spreadsheets. Consequently, when I arrived at the ENS in 2007, I decided to organize a seminar on "Art and Measurement" in which Claire Lemercier, who is passionate about quantitative methods, helped us to create a better framework for our approach. During the subsequent conference I organized on the same subject in December 2008, I observed how many researchers were processing exhibition catalogues' databases. Why not gather our data? It was especially clear that a digital, online database of exhibition catalogues on a global scale and over a long period would be most useful for the history of art.

My own database of exhibitions and catalogues was a good place to start. I had given a part of it to the Musée d'Orsay's Salons database project, but the museum was only interested in exhibitions held by French institutions, and therefore of an academic nature. The Institut national d'histoire de l'art (INHA) which I also contacted in 2006, was interested, but no progress was made. We therefore began to work on our own with funding from the ENS. We quickly hit upon the idea of creating a Geographical Information System (GIS) from the database - thus making it possible to map the many addresses contained in the exhibition catalogues. We

1 This thesis in history, under the direction of Christophe Charle at the Universite Paris 1 - Panthéon Sorbonne, was defended in 2005, then published in 2009 as a book (winner of the Musée d'Orsay prize). 
très vite trouver plus de moyens pour financer la réalisation technique de la base. Nous avons pu recruter des chercheurs spécialistes de géographies et de périodes très différentes des nôtres, pour tester la base sur d'autres espaces-temps, et associer la réalisation de la base à une véritable activité de recherche - un séminaire, des colloques et des publications. L'enjeu était double : réaliser la base avec une interface d'utilisation simple, afin d'aider les historien.ne's de l'art peu familier.e.s des méthodes quantitatives et mondiales (qu'il s'agisse de transferts culturels ou de comparatisme), en leur permettant de s'ouvrir à des approches nouvelles, complémentaires de leurs méthodes traditionnelles ; et encourager l'histoire mondiale et sociale de l'art, alors très peu développée. D'où la rédaction d'une demande de fonds auprès de l'ANR. Le projet a été accepté, pour un financement de quatre ans commencé en novembre 2011, prolongé finalement jusqu'en mai 2016

\section{Comment les corpus ont-ils été délimités ?}

Dans notre groupe, beaucoup voulaient réunir dans la base des sources diverses : avec des catalogues d'expositions, des catalogues de vente, des revues, des catalogues de musées, des répertoires biographiques... Et l'on me demande souvent encore pourquoi la base ARTL@S ne contient pas aussi des sommaires de revues, des fiches biographiques, et même des photos d'œuvres. Le potentiel d'une base de données fait toujours rêver - on se dit qu'on va détecter des réseaux, pister des circulations, raccorder plusieurs bases entre elles, démultiplier les sources, etc. Mais il faut penser utilisation concrète et durabilité de la base : une métabase, où l'on peut mettre «plein plein de choses », c'est bien, mais lorsqu'on y fait une requête, la diversité des données retournées par le système rend particulièrement complexe leur utilisation. On finit par n'y voir plus rien. On ne peut par ailleurs comparer en toute cohérence des données hétérogènes. En outre, techniquement had to quickly find more ways of financing the technical creation of the database. We were able to recruit researchers who were specialists of geographies and of periods very different from ours in order to test the database with other spaces and eras, and link the database to actual research activity - a seminar, conferences, and publications. The stakes were twofold: to create the database with an easy-to-use interface in order to assist art historians who are traditionally unfamiliar with quantitative and global methods ("global" in the sense of both the study of cultural transfer and of comparatism) and help them experiment new approaches that would complement their traditional methods; and to encourage the global and social history of art, which was at that time not very developed. This led to a funding application to the ANR. The project was accepted with funding for four years beginning in 2011, which was extended to May 2016.

\section{How was the corpus defined?}

Several people in our group wished to store diverse sources in the database: exhibition catalogues; sales catalogues; journals and reviews; museum catalogues; biographical indexes - and people still ask me today why the ARTL@S database does not also include journals' tables of content, biographical notes, and even photographs of artworks. The potential of a database is always a reason to dream - one tells oneself that one will detect networks, track circulations, link several databases to one another, increase sources, etc. However, it is important to think of concrete uses and of the durability of the database: a meta-database where one can store many things is all well and good, but as soon as one enters a search query, the diversity of the data found by the system makes the use of that data particularly complex. One ends up not being able to see anything with it. Moreover, it is impossible to compare heterogeneous data with any sort of coherence. 
il n'est pas si facile de fabriquer des systèmes cartographiques qui distingueraient des données selon leur identité de départ : la structure de la base devient ultra-complexe. Mieux valait déjà faire bien une base sur un seul type de source, sachant que le modèle conceptuel associé est déjà très complexe, à cause de la multiplicité des tables qu'il faut construire si l'on veut cartographier toutes les adresses disponibles, et à cause aussi des exigences scientifiques indispensables pour une base de chercheurs : toute information est datée, sourcée, associée à un contributeur, retraçable... En outre, et c'est important, une base qui contiendrait de multiples objets n'a pas de fin, elle n'est jamais complète ! Je n'avais aucune envie de monter un projet de recherches autour d'une base de données jamais terminée, donc impossible à mettre à disposition d'autres chercheurs, voire du grand public. Trop d'argent a été dépensé, quels que soient les pays, et encore aujourd'hui, pour réaliser des bases de données qui finalement ne peuvent être menées jusqu'au bout de leurs ambitions, faute de temps et de moyens, ou qui ne sont pas prêtes à une mise en ligne, faute de limites claires définies dès le début. En bref, j'ai dû imposer une ligne au projet - choisir c'est renoncer - : la base ARTL@S ne contient que des catalogues d'expositions, et elle ne contiendra jamais que cela. Même à l'intérieur de cette vaste catégorie, il faut faire la différence aussi entre collections complètes et catalogues isolés. Un utilisateur lambda a toujours tendance à croire qu'une base de données est complète. En fait, elle donne... ce qu'elle donne ! II faut ne mettre en ligne que des collections complètes - mais aussi faire comprendre ce que l'on met à disposition du public. Nous avons donc imaginé des interfaces publiques d'interrogation et de visualisation qui permettent de passer ce message clair et ne fassent pas croire que la base ARTL@S donne plus qu'elle ne le peut. Pour une requête simple, si vous voulez savoir par exemple quels sont les titres des œuvres exposées par Claude Monet lors de la première exposition impressionniste en 1874, la base donnera une information fiable et
Moreover, technically it is not easy to create cartographic systems that distinguish data according to its original identity; the structure of the database becomes highly complex. It was safer and better to create a database using one sole type of source, knowing that the associated conceptual model is already highly complex because of the multiplicity of tables needed to map all available addresses, and also because of the scientific demands that are essential for a research database: all information is dated, sourced, associated with a contributor, and traceable. In addition, and this is important, a database containing multiple objects would have no end. It would never be complete! I had no desire to embark on a research project around a database that was never-ending and therefore impossible to be made available for other researchers, and thus the public at large, to use. Too much money had been spent, regardless of the country, and is still being spent today, in order to create databases that, in the end, cannot be brought to fruition due to a lack of time and means, or that are not ready to be put online due to a lack of clear limits defined from the start. In short, I had to impose a scope for the project - to choose is to eliminate: the ARTL@S database contains only exhibition catalogues, and it will never contain anything else. Even within this vast category, a distinction needs to be made between complete collections and isolated catalogues. An average user always believes that a database is complete. In fact, it offers only what it contains! Only complete collections should be made available online - but it is also necessary to explain exactly what is being made available to the public. We have worked hard, therefore, to imagine and realize public interfaces for searches and visualisation that would clarify this message and not give the impression that ARTL@S offers more than it can. For a simple search, if you wish to know, for example, the titles of the works shown by Claude Monet at the first impressionist exhibition in 1874, the database will provide reliable and clear information with the source indicated. For advanced quantitative searches, 
claire, à la source évidente. Mais pour des requêtes quantitatives, il faudrait, pour ne pas avoir besoin de réfléchir, que les interfaces de recherche ne permettent de visualiser que des requêtes sur des collections complètes, qu'il est possible de décrire, afin de savoir de quoi l'on parle et de quoi tel pourcentage est le pourcentage, sur quelle géographie et quelle période. Or c'est quelque chose qu'on ne peut pas faire si l'utilisateur ne décide pas lui-même de regarder

quel est le corpus interrogé.

\section{La constitution des bases de données s'appuie-t-elle sur un ancrage théorique et/ou disciplinaire précis ?}

Il était cohérent, au début des années 2000, d'aller contre l'empire d'une histoire molle des mentalités (intéressante mais peu théorisée), et plus encore contre l'empire des monographies, aujourd'hui encore si prégnant en histoire de l'art. II y a tellement d'articles et de livres monographiques qui expliquent que « leur » artiste a tout inventé, déconstruit, tout compris, et qu'il a renouvelé la modernité. Lorsque vous en avez lu vingt-cinq, ça devient fatigant - lorsque vous en avez lu 250, ça finit par être comique. C'est le premier ancrage je dirais sociologique - d'ARTL@S, que j'assume et défends. L'approche sérielle n'a jamais été un réflexe pour une discipline traditionnellement attachée à la mise en valeur d'artistes individuels, au mieux de quelques groupes, et formée surtout à des méthodes de type connoisseurship. Au mieux le sériel est abordé dans les travaux iconologiques (étudier un motif dans un art particulier - une méthode rarement appliquée sur des collections exhaustives) et stylistiques (mais là encore, pas de recherche de l'exhaustivité, et la démarche se veut plutôt critique [Joyeux-Prunel 2008]). Bref, les résultats sont décevants. Ce constat, sévère, est souvent mal pris, surtout lorsque vous arrivez dans un colloque d'histoire de l'art avec des however, without a thorough reflexion beforehand on sources and their representativeness, research interfaces should only allow searches on complete collections, so that one exactly knows what this percentage means, in these precise geography and era. But this is technically possible only if the user defines by him.herself the corpus $s \cdot h e$ wants to search in his.her request.

\section{Is the design of the database supported by a specific theory and/or discipline?}

It made sense, at the beginning of the 2000s, to go against the trend of a "soft" history of mentalities (which was interesting but rarely theorized), and even more so against the empire of monographs, which still play such a strong role in art history today. There are still so many monographic articles and books explaining how "their" artist invented, deconstructed, understood everything, and that he or she renewed modernity. After reading twenty-five of them, it can be tiring - after reading 250 of them, it becomes funny. That is the first - I would say sociological - point of ARTL@S, for which I take responsibility and that I defend. Serial processing has never been an automatic reflex for a discipline that traditionally focuses and emphasizes individual artists - or at best a few groups - following the logics and methods of connoisseurship. At best, serial processing is used in iconological analyses (which study a motif in a particular artform - a method that is rarely used on exhaustive collections) and stylistic analyses (but here again, exhaustive research is rarely a purpose, and the approach is often critical [Joyeux-Prunel 2008]). In short, the results are disappointing. This realization, as harsh as it is, is often poorly received, especially when you arrive at a conference in art history with conclusions drawn from exhaustive 
conclusions tirées de sondages exhaustifs, qui remettent en question les conclusions de chaque recherche individuelle. II y a certes une violence symbolique du chiffre, et de toute prétention à l'objectivité ; mais la discipline dans laquelle je travaille devrait faire plus de place à la question de la représentativité, à rebours de l'idéologie de l'unicité, si constitutive du système de valeur moderniste. Les choses commencent à changer. II y a comme une paix armée avec l'approche quantitative et sociohistorique actuellement. On n'a pas encore compris tout ce qu'apporte la démarche sérielle, ni le fait qu'elle ne met d'ailleurs pas nécessairement en cause les valeurs établies en histoire de l'art. Mettre en série des catalogues et les encoder sous forme de base de données géographique facilite le croisement de sources, une démarche d'autant plus utile que d'autres sources sont rares. Certaines lacunes du travail d'archive sont remplacées par de nouvelles informations produites en connectant des séries de catalogues. En considérant l'information à l'échelle quantitative, le caractère unique des expositions et les hapax d'une période sont noyés dans la masse-ils ne sont plus représentatifs, et des tendances longues peuvent être mises en évidence. L'étape de la visualisation permet aussi de retrouver les exceptions dans la masse, ou d'en identifier de nouvelles. En un sens, l'approche quantitative n'est donc pas contradictoire avec les questionnements qualitatifs, et encore moins avec l'étude de l'exception, des formes et du génie à laquelle on entend parfois qu'il faudrait limiter l'histoire de l'art. Reste à faire comprendre aussi que de « notre côté » - s'il fallait accepter qu'il y ait des camps, selon le reproche qu'on m'a déjà fait d'être « du côté des sociologues » et de celui des « quantitativistes cartographes »-nous ne faisons pas que des statistiques et de la cartographie, que nous nous intéressons aux formes et aux matériaux, que nous lisons les travaux des autres (ce qui n'est pas si réciproque) et que nous allons dans les archives et les musées ! II y a un gros travail d'information à faire en histoire de l'art en France, surtout auprès de la génération qui a plus de cinquante ans, très méfiante envers la sociologie et les humanités numériques. surveys that put into question the conclusions of each individual search. Certainly, there is symbolic violence in the figures, and in all pretence at objectivity, but the discipline in which I work should make more room for the issue of representativeness - running counter to the ideology of uniqueness being a major component of the modernist value system. Things are beginning to change. There is currently a sort of armed truce with the quantitative and socio-historical approach. We have yet to make clear all that serial processing has to offer, nor the fact that it does not, by the way, necessarily call into question established values in the history of art. Processing catalogues in series and encoding them in the form of a geographical database facilitates the cross referencing of sources, and is all the more useful when other sources are rare. Certain gaps in archival work are filled by new information produced by connecting catalogue series. Considering the information on a quantitative level, the unique character of exhibitions and the hapax of a period are submerged in the mass - they are no longer representative, and long tendencies can be revealed. The visualization stage also helps to find exceptions in the mass, or to identify new ones. In one sense, the quantitative approach is therefore not contrary to qualitative questioning, and even less so to the study of exceptions, forms and genius to which it is sometimes said art history should be limited. We also still have to make clear that, on "our side" - if we must accept that there are camps, according to the reproach that has been made to me of being "on the side of the sociologists" and of "quantitative cartographers" - we do more than statistics and cartography; we are interested in forms and material; we read the works of others (which is not that reciprocal); and we do go into archives and museums! There is major informative work to be done in art history in France, especially among the over-fifty generation, still very distrustful of sociology and digital humanities. 
Le deuxième ancrage d'ARTL@S est celui d'une approche qu'on pourrait dire décoloniale. Dans son appel à « une nouvelle écologie du savoir ", l'un des porteurs de ce courant de pensée, Boaventura De Sousa Santos, propose au chercheur de croiser la méthode de sa discipline avec d'autres modes de pensée, en particulier des modes de pensée issus de cultures et de spiritualités « non occidentales » (2009 ; Boidin \& Hurtado López 2009). Si tant est qu'il y ait une culture " occidentale ", ce à quoi je ne crois pas tant que cela, il reste très difficile de sortir de sa propre culture, surtout lorsqu'on vient soi-même d'une conception du monde où c'est ma culture qui apporte le salut, la libération, etc. Pour l'histoire de l'art, il y a une intense réflexion sur le « canon » moderniste en particulier, celui qu'exposent et imposent la plupart des musées d'art moderne, et qui exclut tellement de catégories, aussi bien géographiques, sociales et stylistiques, qu'ethniques, genrées, spirituelles et religieuses. Comment faire place à tout le monde ? I me semble pour ma part que même lorsqu'on introduit des artistes dits périphériques dans le canon, on ne le modifie pas : les nouveaux venus sont adaptés au lit de Procuste des critères du modernisme (originalité, capacité critique, déconstruction des régimes sociaux, genrés ou scopiques de son époque, etc.) ; bref, ils deviennent de petits clones des grands artistes du canon, lesquels n'en sont que plus admirables... Pour décoloniser ce canon, il faut déjà comprendre comment il s'est construit, d'où l'importance d'une histoire sociale et collective de l'art ; et il faut un récit alternatif. Alors comment écrire ce récit alternatif ? II faut déjà disposer d'autres sources que celles produites par les « centres". En augmentant les possibilités d'accès à des catalogues d'expositions qui eurent lieu dans tous les pays d'Europe et pas seulement en France ou en Allemagne, dans tous les pays d'Amérique, latine y compris, et pas seulement à New York ou à Chicago, et jusqu'à l'Asie, l'Afrique, le Moyen-Orient et l'Australie, ARTL@S contribue déjà à donner une autre idée de l'histoire de l'art moderne ou de l'histoire des beaux-
The second point of ARTL@S is to offer an approach that could be called decolonial. In his call for "a new ecology of knowledge," one of the proponents of this new current of thought, Boaventura De Sousa Santos, suggests that researchers cross their discipline methods with other modes of thinking, in particular those of "nonwestern" cultures and spiritualities (2009; Boidin \& Hurtado López 2009). Supposing there is a "western" culture, which I do not much believe is the case, it is still very difficult to step outside one's own culture, especially when we come from a perception of the world in which it is my culture that offers salvation, freedom, etc. For art history, there is an intense reflection, particularly on the modernist "canon" which the majority of museums of modern art expose and impose, and which excludes so many geographical, social and stylistic as well as ethnical, gendered, spiritual, and religious categories. How can we make room for everyone? It seems to me that even when one introduces artists considered peripheral in the canon, one does not modify it: the new arrivals are made to fit the Procrustean bed of modernist criteria (originality, critical capacity, deconstruction of the social, gendered, or scopic systems of its era, etc.). Basically, they become little clones of the major artists of the canon, making the latter all the more admirable. In order to decolonize this canon, it is first necessary to understand how it was constructed, hence the importance of a social and collective history of art, which requires an alternative narrative. So, how can we write this alternative narrative? It first requires access to sources other than those produced by the "centres." By increasing the possibilities of accessing catalogues of exhibitions that took place in all European countries and not just France or Germany, in all America, including Latin America, and not just in New York or Chicago, and as far as Asia, Africa, the Middle East, and Australia, ARTL@S already contributes to giving another idea of the history of modern art or the history of fine arts - and to no longer automatically thinking that an exhibition is ultimately a European exercise, and 
arts - et notamment à ne plus considérer automatiquement que de toute façon, une exposition, c'est un exercice européen, et que ça ne peut rien dire de l'histoire culturelle des périphéries.

On peut aussi réfléchir aux manières de décoloniser nos méthodes, malgré la difficulté à décoloniser nos cœurs et nos sources. Les principales prémisses méthodologiques du canon moderniste contribuent non seulement aux dissymétries dénoncées par l'approche postcoloniale, mais aussi à leur naturalisation : nationalisme méthodologique (assigner un art, un artiste, une œuvre, à une nationalité), corollaire d'une focalisation sur quelques capitales (Paris et New York, pour la période contemporaine) monographie (travailler sur une seule personne, évidemment géniale, qui a tout inventé, tout compris, tout « déconstruit », tout révolutionné) ; formalisme, et son corollaire, le déni des logiques sociales et économiques. On peut choisir d'adopter des méthodes différentes. Parmi les historiens des «périphéries », certains invitent à tenter un nouveau type d'histoire des avant-gardes, une géographie horizontale plus qu'un récit vertical (Piotrowski 2009) ${ }^{2}$. Or justement l'approche sérielle met tout à plat. Pister les circulations des artistes et des œuvres peut y aider aussi (DaCosta Kaufmann, Dossin, Joyeux-Prunel 2015 : 1-22). Ainsi ARTL@S ne fait pas seulement " de la base »: nous formons les chercheurs aux approches transnationales (histoire connectée, transferts culturels, étude des circulations artistiques...) et aux lectures décoloniales, ce qui est le gage d'une émancipation vis-à-vis du mythe du national comme culture autosuffisante. Nous les formons aussi aux méthodes quantitatives, à la cartographie et aux problématiques sociologiques.

\footnotetext{
2 Une traduction française doit paraître aux Presses du Réel, Dijon.
}

that it has nothing to say about the cultural history of peripheral countries.

One could also reflect on ways to decolonize our methods, despite the difficulty of decolonizing our minds and our sources. The main methodological premises of the modernist canon contribute not only to the dis-symmetries denounced by the postcolonial approach, but also to their naturalization: methodological nationalism (assigning an art, an artist, a work, to a nationality), a corollary of a focus on a few capital cities (Paris and New York, for the contemporary period); monography (focus on a single individual who of course is a genius, who invented everything, understood everything, "deconstructed" everything, revolutionised everything); formalism, and its corollary, the denial of social and economic logic. One could choose to adopt different methods. Certain historians of the "Peripheries" invite a new type of history of the avant-gardes, a horizontal geography rather than a vertical narrative (Piotrowski 2009). ${ }^{2}$ And as a matter of fact, serial processing approach puts everything on the same level. Tracking the circulation of artists and artworks can also help there (DaCosta Kaufmann, Dossin \& Joyeux-Prunel 2015: 1-22). Consequently, ARTL@S does not limit itself to the "basics:" we introduce researchers to transnational approaches (connected history, cultural transfers, the study of artistic circulations) and to decolonized readings, which helps them to emancipate from the national myth as self-sufficient culture. We also introduce them to quantitative methods, cartography, and sociological problematics.

2 A French translation is forthcoming at Les presses du réel, Dijon. 
Quels logiciels avez-vous utilisés pour bâtir l'infrastructure des bases de données, et, le cas échéant, pour leur exploitation statistique?

Un projet comme ARTL@S doit être pensé sur plusieurs décennies - donc dans une perspective durable. Je ne sais pas si dans cinq ans nous aurons encore des financements publics pour nos travaux, surtout dans le contexte actuel, tant politique qu'économique. D'où l'importance de choisir des logiciels libres, qui n'impliquent pas des abonnements et autres licences d'utilisation. Nous avons choisi de construire la base avec le logiciel actuellement le plus performant pour développer des structures géoréférencées : PostgreSQL. Les interfaces sont développées aussi avec PHP et Javascript -langages habituels pour ce genre de travail. Pour l'exploitation statistique, même politique. De même, lorsque j'organise des ateliers pour introduire les historiens de l'art aux humanités spatiales, j'utilise des logiciels gratuits : QGis, quoi qu'on en dise, est simple à utiliser, et peut être appris au bout de deux demi-journées de travail.

Pouvez-vous donner en exemple un ou deux résultats scientifiques (attendu ou surprenant) obtenus à l'aide des bases de données ?

Dans l'équipe d'ARTL@S, nous sommes issus souvent de champs de recherches antipodaux et diachroniques, de l'internationalisation de l'art moderne aux $\mathrm{XIX}^{\mathrm{e}}$ et $\mathrm{Xx}$ e siècles à celle de l'art africain. Mais nous tenons les catalogues pour des sources commensurables qui permettent de retracer la mondialisation artistique sur le long terme, de sa dimension spatiale, sociale et économique à la circulation des objets d'art et aux transferts culturels qu'implique cette circulation (Joyeux-Prunel \& Marcel 2015). Nous ne sommes pas les seuls à chercher des éléments de comparaison pour parler

\section{Which software programs were used to build the database infrastructure and, as the case may be, to treat the data statistically?}

A project like ARTL@S has to be considered over several decades - thus from a lasting perspective. I do not know if in five years we will still have public funds for our work, especially in the present political as well as economic context. Therefore, it was important to select free software that would not involve subscriptions and other user licences. To develop the georeferencing structures, we decided to build the database using the best-performing software currently available to develop georeferenced structures: PostgreSQL. The interfaces are also developed with PHP and Javascript - which are common languages for this type of work - for the statistical and even political exploitation. Similarly, when I organize workshops to introduce art historians to spatial humanities, I use free software. QGis, regardless of what is said about it, is simple to use and can be learned in two half-days of work.

\section{Could you offer one or two examples of scientific (whether consensual or surprising)} results obtained with the help of the database?

We in the ARTL@S team often come from research fields that are antipodal and diachronic, from the internationalisation of modern art in the nineteenth and twentieth centuries to that of African art. We value the catalogues, however, as commensurable sources that allow the tracking of artistic globalization over the long term, from its spatial, social, and economic dimension to the circulation of art objects and the cultural transfers that this circulation implies (Joyeux-Prunel \& Marcel 2015). We are not the only ones to look for comparative elements in order to discuss cultural 
d'internationalisation culturelle : avec le développement des Global Art Studies, de plus en plus de chercheurs ressentent le besoin d'un terrain commun pour comparer différents contextes, événements ou trajectoires collectives d'artistes et d'œuvres. Le succès de la base, alors que ses interfaces d'interrogation ne sont même pas déployées, est à relier à ce contexte. II est possible désormais de mettre en œuvre des études plus larges, plus longues, plus ambitieuses peut-être aussi.

Les sources et les outils numériques fournis par ARTL@S aident aussi à étudier ce qu'Arjun Appadurai appelle la " vie sociale des choses » (1986), et à mieux comprendre les contextes successifs d'un processus transculturel (Joyeux-Prunel 2017b). Ils aident à comparer des schémas d'internationalisation, à déceler la présence de certains médiateurs, de réseaux spécifiques, à localiser la trajectoire d'un artefact dans un contexte économique, social ou géopolitique donné. Des cas d'étude comme l'internationalisation de la carrière de Picasso, qui reposa avant 1914 sur une absence totale d'expositions à Paris, tout comme la remise en cause de la prétendue domination mondiale du modernisme états-unien après 1945, pourront désormais être abordés de manière beaucoup plus rapide et efficace qu'avec les méthodes manuelles que nous avions dû utiliser au début des années $2000^{3}$

La base ARTL@S donne aussi à ses contributeurs une idée très nouvelle des chronologies et des géographies possibles de l'art sur près de deux cents ans. En particulier nous avons mis en route une collecte complète d'expositions en Afrique du Nord et au Moyen Orient pour la période 1900-1990 - près de 1400 expositions répertoriées

3 Pour Picasso, voir Béatrice Joyeux-Prunel (2015a ; 2016a et b) ; sur la circulation de la peinture états-unienne en Europe après 1945, voir Dossin (2015). internationalization. With the development of Global Art Studies, more and more researchers feel the need for common ground to compare different contexts, events, or collective trajectories of artists and works of art. The success of the database is related to this context. It is possible from now on to implement studies that are larger, longer, and perhaps also more ambitious.

The sources and digital tools provided by ARTL@S also assist in the study of what Arjun Appadurai calls the "social life of things" (1986), and in better understanding the successive contexts of a transcultural process (Joyeux-Prunel 2017b). The database helps with the comparison of internationalization schemas, with detecting the presence of certain mediators, of specific networks, localizing the trajectory of an artefact in a given economic, social, or geopolitical context. Case studies such as the internationalization of Picasso's career which was based on a total absence of exhibitions in Paris prior to 1914; or the calling into question of the supposed world domination of US modernism after 1945, can from now on be addressed faster and more efficiently than with the manual methods that we had to use at the start of the 2000s. ${ }^{3}$

The ARTL@S database also gives its contributors a very new idea of the possible chronologies and geographies of art over nearly two hundred years. In particular, we have set in motion a complete collection of exhibitions in North Africa and the Middle East from 1900 to 1990 - close to 1,400 exhibitions indexed and referenced before eventually accessing their catalogues. This work illustrates

3 For Picasso, see Béatrice Joyeux-Prunel (2015a; 2016a and b); for the circulation of US paintings in Europe after 1945, see Dossin (2015). 
et référencées, avant d'accéder éventuellement à leurs catalogues. Ce travail montre l'importance d'une activité de type moderne réelle dans l'histoire culturelle d'une large région allant du Maroc à l'Irak, malgré l'absence de mémoire de ce passé proche dans ces régions.

Parmi les autres résultats marquants, le projet GeoMap dont plusieurs publications de Léa Saint-Raymond, Félicie de Maupeou et Julien Cavero rendent compte (2016). Cette reconstitution de la géographie des expositions à Paris entre 1815 et 1955, qui part d'une source homogène, le Bottin du commerce, montre que la culture d'expositions parisienne se déploie dans des espaces très divers : cercles, librairies, journaux, cafés, boutiques de marchands de couleurs, salles louées pour l'occasion, couloirs de cinémas, ateliers, studios de photographes, etc. Elle montre que l'apparition de galeries n'est pas du tout un phénomène des années 1860 comme on le croyait, mais bien du début du xxe siècle. J'étais ravie de ces résultats ; ils ont confirmé ce que j'avais moimême observé, c'est-à-dire l'inexistence du prétendu « système marchand-critique " décrit par Harrison et Cynthia White dans les années 1960, à partir de sources biaisées et insuffisantes, d'études de cas extrapolées, et sans connaissances de fond sur la période. II faudra du temps pour qu'on arrête de citer les White pour parler du marché de l'art à la fin du XIX siècle, mais cela finira par venir ! En croisant les données de la base ARTL@S avec des archives marchandes, artistiques et des catalogues de vente, certains phénomènes méconnus pourront aussi être approfondis, notamment la circulation des œuvres d'art entre marchands, ou le lien entre géographie sociale, géographie artistique et espaces commerciaux de l'art.

Progressivement, nous avons pris conscience de la portée subversive d'ARTL@S : la réunion de sources issues de contrées considérées comme périphériques dans l'histoire mondiale de l'art the importance of genuine modern activity in the cultural history of a wide region reaching from Morocco to Iraq, despite the lack of memory of this recent past in those regions.

Another significant result is the GeoMap project, explained in several publications by Léa Saint-Raymond, Félicie de Maupeou, and Julien Cavero (2016). This reconstitution of the geography of exhibitions in Paris between 1815 and 1955, which began from a homogenous source, the Bottin du Commerce, shows that the culture of Parisian exhibitions was spread among very diverse spaces: clubs, bookshops, journals, cafés, shops selling artists' materials, halls rented for the occasion, cinema hallways, ateliers, photographers' studios, etc. It demonstrates that the arrival of galleries was not a phenomenon of the 1860s as was believed, but of the beginning of the twentieth century. I was delighted with these results. They confirmed what I myself had observed, that is to say, the inexistence of the so-called "dealer-critic system" described by Harrison and Cynthia White in the 1960s, based on biased and insufficient sources, extrapolated case studies, and without a profound understanding of the period. It will take some time before the Whites cease to be cited in discussion of the art market at the end of the nineteenth century, but it will happen! By cross-referencing the data in the ARTL@S database with dealer and artistic archives and sales catalogues, knowledge about certain lesser-known phenomena could also be deepened, particularly concerning the circulation of works of art between dealers, or the connections between the social and artistic geography, and commercial spaces of art.

Over time, we have become aware of the subversive significance of ARTL@S. The merging of sources from regions considered peripheral in the world in the global history of art and artistic 
et des modernités artistiques remet en cause le préjugé favorable accordé à quelques centres par les historiens et les musées - en particulier Paris avant 1945 et New York après cette date. Cela devient une manière de provincialiser les centres symboliques du canon artistique, à laquelle beaucoup appellent (Joyeux-Prunel 2015b). ARTL@S donne un cadre méthodologique et théorique utile, même s'il n'est pas exclusif, pour une relecture de l'histoire et de la géographie mondiale de l'art depuis le XIX ${ }^{\mathrm{e}}$ siècle (Dossin 2015 ; Joyeux-Prunel $2016 \mathrm{c}$ et $2017 \mathrm{a}^{4}$ ). Avec une approche transnationale de l'histoire de l'art, un questionnement des géographies artistiques imposées par le canon, une ouverture à d'autres géographies, la prise en compte des questions géopolitiques dans l'histoire de l'art, le refus d'oublier les logiques sociales, les transferts culturels et les questions de marché, j'ose croire qu'on peut essayer d'écrire une autre histoire des modernités artistiques - et que ça vaut la peine d'y

passer beaucoup, beaucoup de temps.

\section{Qu'envisagez-vous pour la pérennité et l'accessibilité de ces données numérisées ?}

La base de catalogues a été mise en ligne tout récemment, en janvier 2018. Nous améliorons progressivement son interface d'interrogation et de visualisation. La nouvelle de sa mise en ligne, pour laquelle nous n'avons pas fait pour l'instant de publicité, a immédiatement circulé sur les réseaux sociaux. La base, quoique encore peu remplie, a beaucoup de succès, non seulement auprès des historien'ne's de l'art, mais aussi auprès des acteur.rice's du marché de l'art - marchand.e.s, expert.e.s, héritier.ère.s, etc. -, ainsi que des institutions patrimoniales à la recherche de contenus numériques novateurs et interactifs pour valoriser leurs événements en particulier leurs expositions. Raison de plus pour penser sérieusement à sa pérennité.

4 Le troisième volume (1945-1968) doit paraitre en 2018. modernity, challenges the favourable consideration accorded by historians and museums to a few centres-Paris prior to 1945 in particular, and New York from then on. This has become a way of provincializing the symbolic centres of the artistic canon - a new interpretation that many call for (Joyeux-Prunel 2015b). ARTL@S offers a useful, and not exclusive, methodological and theoretical tool for a re-reading of the global history and geography of art since the nineteenth century (Dossin 2015; Joyeux-Prunel 2016c and $\left.2017 a^{4}\right)$. With a transnational history of art that challenges the artistic geographies imposed by the canon, an openness to other geographies, the taking into account of geopolitics in the history of art, and the refusal to ignore social contexts, cultural transfers, and market issues, I dare to believe that we could attempt to write another history of artistic modernities - and that it is worth spending a great deal of time doing so.

\section{What plans do you have with regard to the perpetuity and accessibility of this database?}

The catalogues database was published online in January 2018. We develop and expand its query and visualization interface gradually. We did not make much publicity about this publication, but the news circulated immediately on the social networks. The database, however still to be augmented, has a great success, not only among art historians but also among many players in the art market - merchants, experts, inheritors, etc. - as well as museums and other art institutions in search of new digital and interactive content to enhance their events, particularly their exhibitions.

\footnotetext{
4 The third volume (1945-1968) is forthcoming in 2018.
} 
Du côté du marché, j'ai longtemps pensé cohérent de ne mettre publiquement en ligne que certains niveaux de la base, c'est-àdire tout ce qui concerne les expositions, leur chronologie et leur géographie, les artistes et leurs circulations. L'idée était que ce qui permet de valoriser les œuvres (donc d'augmenter des prix) ne serait accessible qu'aux contributeurs, chercheurs volontaires associés au projet, ou bien en échange d'une contribution financière en fait modeste lorsqu'on la compare à ce que nos institutions de recherche ont investi dans ARTL@S. Que représente pour une grande galerie un abonnement annuel, par rapport à ce qu'elle peut trouver dans la base ARTL@S pour valoriser les œuvres qu'elle vend? Mais la mise en place des éléments juridiques et techniques d'un tel projet était en fait très, trop complexe, et il aurait fallu pour cela que je monte moi-même une start-up. Aucune envie ! Je me suis rendu compte surtout, en avançant, qu'il valait mieux passer du temps pour faire avancer ARTL@S, peaufiner nos interfaces - si elles sont belles, convaincantes, elles seront refinancées ; et qu'il fallait faire confiance au projet. Nous avons toujours pu trouver l'argent dont nous avions besoin jusqu'ici.

J'ai pris le parti aussi de travailler à des partenariats avec des institutions patrimoniales et plusieurs autres projets de recherche qui nous aident à étendre les collections. Ces équipes nous ont aidés depuis plusieurs années à mieux voir tout ce que pouvait donner la base à ceux qui l'utilisent. Nous avons pu ainsi orienter de la manière la plus cohérente possible nos travaux sur les interfaces de visualisation et de requête. Plusieurs équipes muséales nous ont sollicités pour une collaboration - ARTL@S devant fournir des solutions techniques et des sources pour faciliter l'approche cartographique aussi bien dans le cadre de sites numériques et d'animations, que pour des bornes disposées au sein de futures expositions, à destination des publics. L'idée est de fournir à nos
In market terms, for a long time I thought it would make sense to have only certain levels of the database available to the public, that is to say those which concern the exhibitions, their chronology and geography, the artists and their circulations. The idea was that information which would help to increase the prestige of the works (and therefore increase prices) would only be accessible for free to the contributors and scholars associated with the project, or to others in exchange for a financial contribution - modest in reality when compared with the amount our research institutions have invested in ARTL@S. After all, what is an annual subscription for a major gallery in comparison with the information that it can find in the ARTL@S database to increase the value of the works it sells? However, arranging the legal and technical elements of such a project was, in fact, much too complex, and would have required me to build my own start-up company. I have no desire to do that! I realised, above all, as things progressed that it is better to spend my time moving ARTL @S forward and finetuning our interfaces - if they are attractive and convincing they will be funded again; I have confidence in the project. Up to this point, we have always been able to find the money we need for it.

I also resolved to work on partnerships with museums, art institutions and other research projects that help us to extend the collections. These teams have helped us for several years to see all that the database has to offer. We have thus been able to position our work on visualization and search interfaces in the most logical manner possible. Several museum teams have sought to collaborate with us - with ARTL@S having to provide technical solutions and sources to facilitate the cartographic approach for digital and animation sites, as well as for terminals available in future exhibitions designed for the public. The idea is to provide our partners with "widgets," personalize-able interface sections for quantitative, spatial, and textual analysis of the data 
partenaires des « widgets », des bouts d'interfaces personnalisables d'analyse quantitative, spatiale et textuelle des données contenues dans la base, qu'ils déploieront sur leurs propres sites et selon leurs propres problématiques. Nous travaillons avec le RKD (Institut royal d'histoire de l'art, Leyde) dans le cadre d'une exposition pour le Petit Palais et le musée Van Gogh sur les artistes néerlandais à Paris au XIX $\mathrm{X}^{\mathrm{e}}$ siècle ; le musée Picasso, pour un projet sur Picasso et la Méditerranée ; I'Asian/Pacific/American Institute et son projet de «Virtual Asian American Art Museum »; un projet basé à l'Open University en Grande-Bretagne, sur les expositions dans I'Inde britannique entre 1888 et 1914 ; une équipe de l'Université de São Paulo, sur les biennales brésiliennes ; le projet MoDe(s) de l'Université de Barcelone ; et pour nos propres équipes dont il faut mettre en ligne toutes les recherches, en particulier celles de Léa Saint-Raymond, Félicie de Maupeou, Julien Cavero et Tatiana Debroux sur la géographie artistique parisienne aux XIX et $x x^{e}$ siècles, et les travaux d'Annie et Gabriel Verger sur les élèves de l'Académie de France à Rome.

Mais la durabilité du projet dépendra surtout de notre manière d'améliorer le processus de collecte des données, qui est encore trop manuel, chronophage, producteur d'erreurs et qui nous oblige à renoncer à certaines informations, en particulier les illustrations contenues dans les catalogues d'expositions. Nous avons beaucoup de partenaires, déjà, surtout du côté des pays arabes, mais aussi en Israël, en Amérique latine et en Espagne, qui souhaiteraient contribuer à la base mais ne peuvent faire mieux que nous envoyer des photographies de catalogues, et éventuellement relire des données après traitement. Après dix-huit mois de travail avec une équipe de l'Université de São Paulo, nous avons compris la difficulté de former des contributeurs à distance, sur une interface francophone vraiment complexe. L'équipe d'Ana Paula Simioni et Eduardo Dimitrov n'a pas renoncé pourtant ! C'est available in the database that they can display on their own sites and according to their own issues. We work with the RKD (Royal Institute for Art History, Leyden) for an exhibition at the Petit Palais in Paris and the Van Gogh Museum on Dutch artists in Paris in the nineteenth century; the Picasso museum for a project on Picasso and the Mediterranean; the Asian/Pacific/American Institute and its "Virtual Asian American Art Museum" project; a project based at the Open University in the UK, on exhibitions in British India between 1888 and 1914; a team from the University of São Paulo on the São Paulo Biennales; the University of Barcelona's MoDe(s) project; and for our own teams whose entire research we need to put online, in particular that of Léa Saint-Raymond, Félicie de Maupeou, Julien Cavero, and Tatiana Debroux on the Parisian artistic geography of the nineteenth and twentieth centuries, and the works of Annie and Gabriel Verger on the students of the Académie de France in Rome.

However, the durability of the project will depend most of all on the manner in which we improve the data collection process, which is still too manual, time-consuming, and error-prone, and which requires us to leave out certain information, in particular the illustrations contained in the exhibition catalogues. We already have many partners, especially from Arab countries, but also in Israel, Latin America, and Spain, who would like to contribute to the database but can do no more than send us photographs of catalogues, and sometimes re-read the data once it has been processed. After eighteen months of work with a team from the University of São Paulo, we understand the difficulty of training contributors from a remote location, on a really complex French database. However, Ana Paula Simioni and Eduardo Dimitrov's team did not give up! It is with them in mind that I am currently working on a partnership with a team of Computer Vision specialists. The aim is to automatically 
en pensant à eux que je travaille actuellement à un partenariat avec des spécialistes en intelligence visuelle, "Computer Vision » en anglais. L'objectif est de traiter automatiquement les numérisations envoyées par nos partenaires pour les ajouter dans la base après une reconnaissance et un encodage systématique des textes et des images des catalogues. À partir de ces données, il doit être possible de faire une étude assez puissante de la mondialisation artistique sur un siècle. Nous travaillerons sur une série exhaustive de catalogues de biennales - un type d'exposition qui après 1950 se mondialise et se multiplie de manière passionnante -, et sur longue période, 1890-2010, si nous y parvenons techniquement. Nous pourrons tirer de ces collections incroyables des informations sur la mondialisation et la circulation artistiques dans toutes leurs dimensions (économique, géographique, sociologique, esthétique, stylistique, politique, genrée...). Nous pourrons étudier cela non seulement à partir des informations textuelles contenues dans les catalogues, mais aussi en étudiant leurs reproductions, leur contenu photographique et leur mise en page. L'équipe est en train d'être montée, du Brésil au Japon. C'est une belle et passionnante aventure de recherche et d'amitié qui s'esquisse

Béatrice Joyeux-Prune École normale supérieure, université Paris Sciences Lettres Département d'histoire et théorie des arts / Institut d'histoire moderne et contemporaine, labex TransferS.

\section{Références bibliographiques}

Appadural Arjun (dir.) (1986). The Social Life of Things. Commodities in Cultural Perspective. Cambridge, Cambridge University Press. process the scans sent by our partners in order to add them into the database after recognition and systematic encoding of the catalogues'texts and images. From this data, it should be possible to conduct a fairly powerful study of artistic globalisation over a century. We are working on an exhaustive series of biennial catalogues - a form of exhibition that after 1950 has been going global and has multiplied in an exciting way - and over a long period, 1890-2010, if we achieve it technically. We want to draw from these incredible collections information on artistic globalisation and circulation in all of their dimensions (economic, geographic, sociological, aesthetic, stylistic, political, gendered, etc.). We will do this not only from the textual information contained in catalogues, but also by examining reproductions, photographic content, and page format. The team is in the process of being assembled, from Brazil to Japan. It is the start of a promising and fascinating adventure in research and in friendship!

Béatrice Joyeux-Prunel

École normale supérieure, université Paris Sciences Lettres -

(hépartement d'histoire et théorie des arts / Institut d'histoire moderne et contemporaine, labex TransferS.

\section{References}

Appadural Arjun (ed.) (1986). The Social Life of Things. Commodities in Cultural Perspective. Cambridge, Cambridge University Press. 
BoIdIN Capucine \& HURTADo López Fátima (2009). « La philosophie de la libération et le courant décolonial ». Cahiers des Amériques latines, 62(3) : 17-22.

DaCosta Kaufmann Thomas, Dossin Catherine, Joyeux-Prunel Béatrice (2015). " Reintroducing Circulations : Historiography and the Project of Global Art History ". In DaCosta KaUfmann Thomas, Dossin Catherine \& JOYEuX-Prunel Béatrice (dir.). Circulations in the Global History of Art. Farnham, Ashgate : 1-22.

Dossin Catherine (2015). The Rise and Fall of American Art 1940s-1980s: A Geopolitics of Western Art Worlds. Farnham, Ashgate.

JOYEUX-PRUNELBéatrice (2008). «L'histoire de l'art et le quantitatif ». Histoire \& Mesure, XXIII(2) : 3-34.

JoyeuX-Prunel Béatrice (2009). "Nul n'est prophète en son pays »? L'internationalisation de la peinture avant-gardiste parisienne (18551914). Paris, Musée d'Orsay/Nicolas Chaudun.

Joyeux-Prunel Béatrice \& Marcel Olivier (2015). « Exhibition Catalogues in the Globalization of Art. A Source for Social and Spatial Art History ». Artlas Bulletin, IV(2). [En ligne] http://docs.lib.purdue.edu/ artlas/vol4/iss2/8/ [consulté le 15 janvier 2018].

Joyeux-Prunel Béatrice (2015a). « La construction internationale de l'aura de Picasso avant 1914. Expositions différenciées et processus mimétiques ». In Revoir Picasso, actes du colloque du musée Picasso, Paris. [En ligne] http://revoirpicasso.fr/circulations/la-constructioninternationale-de-laura-de-picasso-avant-1914-expositions-differencieeset-processus-mimetiques---b-joyeux-prunel// [consulté le 15 janvier 2018].

Joyeux-Prunel Béatrice (2015b). «Provincializing Paris. The CenterPeriphery Narrative of Modern Art in Light of Quantitative and Transnational
BoIDIN Capucine \& HURTADO LóPEZ Fátima (2009). "La philosophie de la libération et le courant décolonial." Cahiers des Amériques latines, 62(3): 17-22.

DaCosta Kaufmann Thomas, Dossin Catherine, Joyeux-Prunel Béatrice (2015). "Reintroducing Circulations: Historiography and the Project of Global Art History." In DaCosta KaUfmann Thomas, Dossin Catherine, Joyeux-Prunel Béatrice (eds.). Circulations in the Global History of Art. Farnham, Ashgate: 1-22.

Dossin Catherine (2015). The Rise and Fall of American Art 1940s-1980s: A Geopolitics of Western Art Worlds. Farnham, Ashgate.

JOYEUX-PRUNEL Béatrice (2008). "L'histoire de l'art et le quantitatif." Histoire \& Mesure, XXIII(2): 3-34.

Joyeux-Prunel Béatrice (2009). "Nul n'est prophète en son pays" ? L'internationalisation de la peinture avant-gardiste parisienne (18551914). Paris, Musée d’Orsay/Nicolas Chaudun.

Joyeux-Prunel Béatrice \& MARCel Olivier (2015). "Exhibition Catalogues in the Globalization of Art. A Source for Social and Spatial Art History." Artlas Bulletin, IV(2). [On line] http://docs.lib.purdue.edu/artlas/vol4/ iss2/8/ [accessed on 15 february 2018].

Joyeux-Prunel Béatrice (2015a). "La construction internationale de l'aura de Picasso avant 1914. Expositions différenciées et processus mimétiques." In Revoir Picasso, actes du colloque du musée Picasso, Paris. [On line] http://revoirpicasso.fr/circulations/la-construction-internationalede-laura-de-picasso-avant-1914-expositions-differenciees-et-processusmimetiques---b-joyeux-prunel/ [accessed on 15 february 2018].

Joyeux-Prunel Béatrice (2015b). "Provincializing Paris. The CenterPeriphery Narrative of Modern Art in Light of Quantitative and Transnational 
Approaches 》. Artl@s Bulletin, IV(1) : Article 4. [En ligne] http://docs.lib. purdue.edu/artlas/vol4/iss1/4/ [consulté le 15 janvier 2018].

JOYEUX-PRUNEL Béatrice (2016a). « ¿Exponer al cubista sin cubismo ? De cómo Kahnweiler llegó a convencer a Alemania - e incluso al mundo entero - del aura de Picasso mediante su pedagogía expositiva (19081914) ». In Picasso. Registros Alemanes, cat. exp. Malagá, Museo Picasso : 258-273.

Joyeux-Prunel Béatrice (2016b). « Den Kubisten ausstellen, ohne Kubismus ? » In Lebrero Stals José (dir.) ù, Picasso und Deutschland, Kunsthalle Würth, Schwäbisch Hall, 6. April 2016-2018. September 2016. Künzelsau/Malaga, Die Sammlung Würth in Kooperation mit dem Museo Picasso Malaga : 258-273.

JoyeuX-Prunel Béatrice (2016c). Les Avant-gardes artistiques 18481918. Une histoire transnationale. Paris, Gallimard.

JoYeuX-Prunel Béatrice (2017a). Les Avant-gardes artistiques 19181945. Une histoire transnationale. Paris, Gallimard.

JOYEUX-PrUneL Béatrice (2017b). «Circulations, resémantisations. Le palimpseste aporétique ». Art|@s Bulletin, VI(2) : 1-17. [En ligne] http:// docs.lib.purdue.edu/artlas/vol6/iss2/12/ [consulté le 15 janvier 2018].

PIOTRowski Piotr (2009). In the Shadow of Yalta. Art and the Avant-garde in Eastern Europe, 1945-1989. Londres, Reaktion Books.

Saint-Raymond Léa, de Maupeou Félicie, Cavero Julien (2016). « Les rues des tableaux: The Geography of the Parisian Art Market 18151955 ».Art/@s Bulletin, V(1) : Article 10. [En ligne] http://docs.lib.purdue. edu/artlas/vol5/iss1/10/ [consulté le 15 janvier 2018]

Sousa Santos Boaventura de (2009). « Beyond Abyssal Thinking. From Global Lines to Ecologies of Knowledges ». [En ligne] http://www.eurozine. com/ [consulté le 15 janvier 2018].
Approaches." Artl@s Bulletin, IV(1): Article 4. [On line] http://docs.lib. purdue.edu/artlas/vol4/iss1/4/ [accessed on 15 february 2018].

Joyeux-Prunel Béatrice (2016a). “¿Exponer al cubista sin cubismo ? De cómo Kahnweiler llegó a convencer a Alemania - e incluso al mundo entero - del aura de Picasso mediante su pedagogía expositiva (19081914)." In Picasso. Registros Alemanes, ehx. cat. Malagá, Museo Picasso: 258-273.

JoYeux-Prunel Béatrice (2016b). "Den Kubisten ausstellen, ohne Kubismus ?" In Lebrero Stals José (ed.), Picasso und Deutschland, Kunsthalle Würth, Schwäbisch Hall, 6. April 2016-2018. September 2016. Künzelsau/Malaga, Die Sammlung Würth in Kooperation mit dem Museo Picasso Malaga: 258-273.

JoYeux-Prunel Béatrice (2016c). Les Avant-gardes artistiques 18481918. Une histoire transnationale. Paris, Gallimard.

JoyeuX-Prunel Béatrice (2017a). Les Avant-gardes artistiques 19181945. Une histoire transnationale. Paris, Gallimard.

JOYeux-Prunel Béatrice (2017b). "Circulations, resémantisations. Le palimpseste aporétique." Art!@s Bulletin, VI(2): 1-17. [On line] http://docs. lib.purdue.edu/artlas/vol6/iss2/12/ [accessed on 15 february 2018].

PIOTRowskI Piotr (2009). In the Shadow of Yalta. Art and the Avant-garde in Eastern Europe, 1945-1989. Londres, Reaktion Books.

Saint-Raymond Léa, Maupeou (DE) Félicie, CaVero Julien (2016). "Les rues des tableaux: The Geography of the Parisian Art Market 1815-1955." Artl@s Bulletin, V(1): Article 10. [On line] http://docs.lib.purdue.edu/artlas/ vol5/iss $1 / 10 /$ [accessed on 15 february 2018].

Sousa SANTOS Boaventura de (2009). "Beyond Abyssal Thinking. From Global Lines to Ecologies of Knowledges." [On line] www.eurozine.com [accessed on 15 february 2018]. 